\title{
Development of Biochemistry e-Module to Improve Students' Higher Order Thinking Skills
}

\author{
Freddy Tua Musa Panggabean ${ }^{1, *}$ Pasar Maulim Silitonga ${ }^{1}$ Marudut Sinaga ${ }^{1}$
}

\author{
${ }^{I}$ Department of Chemistry Education, Faculty of Mathematics and Natural Sciences, Universitas Negeri Medan, Jl. \\ Willem Iskandar Pasar V, Medan, Indonesia \\ *Corresponding author. Email: freddypanggabean@unimed.ac.id
}

\begin{abstract}
Generations in the 21st century must be prepared to have competencies and skills that include: critical thinking and problem-solving competencies, creativity, communication skills, and the ability to work together. The application of HOTS abilities in the learning process makes students more resilient and able to solve their own problems. The object of this research is the development of a general chemistry e-module for biochemical material to improve students' higher order thinking skills. E-modules are prepared and developed by taking into account the material and media aspects and are designed based on HOTS. The results of the validation and implementation of the developed e-module have been declared valid and proven effective in increasing student HOTS on biochemical material. Student responses to the resulting e-modules are also very positive because the e-modules are designed using the Kvisof Flipbook Maker application which can be opened on laptops, computers or Android devices so that material can be repeated anytime and anywhere and materials and questions are compiled HOTS-based to train and improve students' HOTS skills.
\end{abstract}

Keywords: E module, General Chemistry, HOTS

\section{INTRODUCTION}

The results of the International Program for International Student Assessment (PISA) study show that the achievement of reading literacy, mathematical literacy, and scientific literacy achieved by Indonesian students is very low and can only occupy the bottom 10 of 65 countries. The low PISA study results are certainly caused by many factors and one of the contributing factors is because students in Indonesia are not trained in solving contextual problems, demanding reasoning, argumentation and creativity in solving them, where these questions are characteristic of the questions TIMS [1].

Higher Order Thinking Skill (HOTS) is part of Bloom's taxonomy revised in the form of operational verbs consisting of analysis (C4), evaluation (C5) and creative (C6) which can be used in preparing questions. HOTS is a high-level thinking skill that demands critical, creative, analytical thinking on information and data in solving problems [2], and is a type of thinking that tries to explore questions about existing knowledge related to issues that are not clearly defined. and have no definite answer [3].
HOTS is learning that is designed to prepare the $21 \mathrm{st}$ century generation. The 21 st century generation must be prepared to have competencies and skills that include: critical thinking and problem-solving competencies, creativity, communication skills, and the ability to work together [4]. HOTS measures the ability to: 1) transfer concepts, 2) process and apply information, 3) relate different kinds of information, 4) solve problems using information, and 5) examine ideas and information critically. HOTS is defined as the ability to use the mind to solve problems at hand. Therefore, one must understand, interpret, analyze, and interpret information. HOTS also teaches a person to be critical in evaluating information, making conclusions, and making generalizations. In the revised Bloom's Taxonomy, HOTS is a cognitive ability at the level of application, analysis, evaluation, and innovation [5].

The most important element and the spearhead of HOTS learning change is the teacher or lecturer who wants to change the learning mindset that is applied. Learning that used to be dominated by monologue and lecture systems must be changed with a new pattern that activates the potential and abilities of students optimally by applying HOTS abilities. The application of HOTS 
abilities in the learning process makes students more resilient and able to solve their own problems [6].

The HOTS ability of each individual is certainly different, depending on the exercises that are often done to develop it. In addition to the use of learning strategies or models by teachers/lecturers, other factors that also determine the success of students in learning, including in training students' higher-order thinking skills, are teaching materials and media used by students as learning resources. Teaching materials that can be used by students as media and independent learning resources have an important role in improving and developing higher order thinking skills.

An educator, including lecturers, is also required to be able to design teaching materials and media that are oriented towards active student involvement and are expected to stimulate students to be able to think at a higher level. The development of appropriate teaching materials and in accordance with student learning needs is the best effort to improve student academic achievement and foster students' higher-order thinking skills. To produce tools or teaching materials of good quality, teaching materials must be prepared and planned carefully to produce a good learning activity.

Teaching materials are not only in the form of books or worksheets based on print media. Non-print-based teaching materials can also be used in learning, for example in the form of electronic teaching materials. Currently, electronic-based teaching materials can be easily obtained due to the presence of information technology network devices. Through this information technology network, educators can use it as teaching materials easily. The ease of accessing networks and information technology is an advantage for the world of education. The world of education can be used as a means of advanced learning and learning is not only conventional but can also be integrated through online.

Along with the development of technology and information in the current digital era, efforts to improve the quality of learning can be carried out through the use of technology in a system known as online learning, one of which is by utilizing media and teaching materials in the form of e-modules or can be called electronic modules. E-Modul is a product of digital-based nonprinted teaching materials that are independently designed to be learned by students. An E-Modul or electronic module is an electronic version of a printed module that can be read on a computer and designed with the required software. E-module is a tool or learning tool that contains materials, methods, limitations and ways of evaluating that are designed systematically and attractively to achieve the expected competencies according to the level of complexity electronically. Emodule is a display of information in book format that is presented electronically using a hard disk, diskette, CD, or flash disk and can be read using a computer or electronic book reader [7].

E-Modul is a product of digital-based non-printed teaching materials that are independently designed to be studied by students. E-Modules are also called media for independent learning because they are equipped with instructions for self-study. It can be said that the reader can carry out learning activities without the presence of the teacher directly [8]. Furthermore, using e-modules can facilitate students in learning both independently and conventionally. The e-module is equipped with instructions for independent study, so that students can study according to their abilities. Its advantages compared to the print module are that its interactive nature makes it easy to navigate, allows displaying/loading of images, audio, video and animation and is equipped with formative tests/quizzes that allow immediate automatic feedback. The use of web modules and media learning will ensure student control, flexibility, context-free and also relatively free of social conventions.

The e-module that will be developed in this research is compiled using the Kvisof Flipbook Maker software or application. Kvisoft Flipbook Maker is an application for creating e-books, e-modules, e-papers and e-magazines. Not only in the form of text, with this application you can insert images, graphics, sounds, links and videos on the worksheet. In general, this multimedia device can include files in the form of pdf, images, videos and animations so that the flip book maker is made more attractive. In addition, flip book maker has design templates and features such as backgrounds, control buttons, navigation bars, hyperlinks and back sounds. Students can read by feeling like reading a book physically because there is an animation effect where when switching pages, it will look like physically opening a book. The final result can be saved to HTML, exe, zip, screen saver and app formats [9].

The developed e-module is also oriented towards Higher Order Thinking Skill (HOTS). This is to answer the problems that researchers encountered while teaching lectures where students' high order thinking skills (HOTS) were still low. The use of HOTS-oriented emodules will lead students to find solutions to problems independently and this will provide a concrete experience in solving problems so as to grow and train students' higher order thinking skills.

\section{METHODS}

This research belongs to the type of research and development (R\&D) which is a type of research that produces products instead of testing a theory. Research and development are a process used to develop and validate educational products [10], test the effectiveness of these products [11], and be accountable [12]. The results of this development research are HOTS-oriented 
e-modules in the General Chemistry course, Biochemistry material to increase students' HOTS.

The development model used refers to the ADDIE development model. The procedure is carried out through several stages, including: (a) Analysis, namely conducting an analysis to collect information related to student needs and reviewing literature related to the product being developed; (b) Design, is the stage carried out to identify goals and design e-modules to be developed; (c) Development, is the stage to realize the design into a product that is ready to be implemented; (d) Implementation, namely implementing the developed product, namely the HOTS-oriented e-module in the General Chemistry course on Biochemistry; and (e) Evaluation, namely conducting an evaluation by analyzing the effectiveness of the use or application of emodules on students' higher order thinking skills (HOTS).

Techniques and instruments used in this study include: interviews, validation sheets and tests. Interviews are used for data collection when conducting research as a preliminary study material to look for problems to be studied. Interviews were also used in product trials both at the time of validation to experts and product trials in the field as a consideration in improving the teaching materials developed. The validation sheet is used to obtain data on the results of the expert's validation of the developed HOTS-based e-module. The results of the expert validator's assessment will be tested for feasibility or validity. The test instrument was arranged to obtain data on students' higher order thinking skills (HOTS) on Biochemistry. The test is structured and developed according to the HOTS indicators including C4, C5 and C6.

The research data were analyzed in stages to determine the feasibility (validity) and effectiveness of the developed e-module. The validity of the e-module that has been developed can be seen from the validation sheet filled in by the expert validator and the results of questions and answers during the validation process. The effectiveness of the developed e-module product is obtained from the results of the student's higher order thinking ability (HOTS) test. The effectiveness test of the developed e-module was analyzed from the increase in HOTS using a t-test or a paired sample t-test approach with the help of the SPSS program.

\section{RESULT AND DISCUSSION}

\subsection{E-module validation results on material aspects}

The validity (feasibility) of the e-module on the material aspect was validated by 3 expert validators. The results of the expert validators on the Biochemical material e-module obtained an average total score of 4.17 or declared valid. In the aspect of the feasibility of the content obtained an average score of 4.11 or classified as valid; on the aspect of the feasibility of the presentation obtained an average score of 4.23 or classified as valid; on the aspect of language feasibility obtained an average score of 4.15 or classified as valid; and in the HOTS assessment aspect, an average score of 4.20 is obtained or is classified as valid. Overall, the results of the expert validator's assessment on the material aspect concluded that the e-module on the developed Biochemistry material was valid or feasible to be applied in learning (Table 1).

\subsection{E-module validation results on material aspects}

The validity (feasibility) of the e-module on the media aspect of teaching materials was validated by 3 expert validators. The results of the expert validators on the Biochemical material e-module on the media aspect obtained an average total score of 4.18 or declared valid. In the aspect of software engineering obtained an average score of 4.30 or classified as valid; on the aspect of the interface display obtained an average score of 4.11 or classified as valid; on the aspect of visual communication obtained an average score of 4.04 or classified as valid; and in the aspect of the characteristics of the e-module obtained an average score of 4.27 or classified as valid. Overall, the results of the expert validator's assessment on the media aspect concluded that the e-module on the developed Biochemistry material was valid or feasible to be applied in learning (Table 2).

\subsection{Product effectiveness}

The effectiveness of the e-module was analyzed based on the achievement of student learning outcomes before and after using the resulting e-module. This stage is carried out for students and is carried out in 3 (three) stages including: (1) the initial stage, namely giving the initial HOTS test (pretest) before students are given action using the e-module generated through the CBT application, (2) the second stage is the process learning where students learn online by utilizing e-modules that can be accessed and downloaded using a laptop, computer or android on the department's e-learning site, and (3) the third stage is giving the final HOTS test (posttest) through the CBT application.

The effectiveness of the developed e-module was analyzed from the increase in learning outcomes obtained by students in completing the HOTS test on Biochemistry by using a pretest-posttest design. The test results were analyzed by t-test or paired sample t-test approach with the help of SPSS program. The students' initial HOTS on Biochemistry material before being given an e-module (pretest) obtained an average value of 53.50 and a standard deviation of 7.445 with the lowest score of 35 and the highest score of 65 and the data having a normal distribution (Kolmogorov Smirnov test $=0.147$ and $\mathrm{p}=$ 0.099). After taking action through learning using e- 
modules from the posttest results obtained an average student HOTS score of 84.67 and a standard deviation of 7.871 with the lowest score of 65 and the highest score of 100 and the data has a normal distribution (Kolmogorov Smirnov test $=0.151$ and $\mathrm{p}=0.079$ ).
The implementation of e-modules in Biochemistry learning has also proven effective in increasing student HOTS. The effectiveness of the e-module was fulfilled statistically based on the increase in students' ability to complete the HOTS instrument which was carried out

Table 1. The results of the validation of the biochemical e-module on the aspects of assessment

\begin{tabular}{lccccc}
\hline \multirow{2}{*}{ Aspects of assessment } & \multicolumn{3}{c}{ Validator (mean score) } & \multirow{2}{*}{ Total mean } & \multirow{2}{*}{ Criteria } \\
\cline { 2 - 4 } & I & II & III & & \\
\hline Content eligibility & 3.83 & 4.33 & 4.17 & 4.11 & Valid \\
Serving eligibility & 4.10 & 4.30 & 4.30 & 4.23 & Valid \\
Language eligibility & 3.78 & 4.33 & 4.33 & 4.15 & Valid \\
HOTS Rating & 3.80 & 4.40 & 4.40 & 4.20 & Valid \\
\hline \multicolumn{7}{c}{ Mean total validation } & & 4.16 & Valid \\
\hline
\end{tabular}

Table 2. The results of the validation of the biochemical e-module on the aspects of assessment

\begin{tabular}{lccccc}
\hline \multirow{2}{*}{ Aspects of assessment } & \multicolumn{3}{c}{ Validator (mean score) } & \multirow{2}{*}{ Total mean } & \multirow{2}{*}{ Criteria } \\
\cline { 2 - 4 } & I & II & III & & \\
\hline Software engineering & 4.00 & 4.40 & 4.50 & 4.30 & Valid \\
Interface view & 3.78 & 4.22 & 4.33 & 4.11 & Valid \\
Visual communication & 3.63 & 4.25 & 4.25 & 4.04 & Valid \\
Characteristics of e-module & 3.80 & 4.60 & 4.40 & 4.27 & Valid \\
\hline \multicolumn{7}{c}{ Mean total validation } & & 4.18 & Valid \\
\hline
\end{tabular}

Table 3. Product effectiveness results (t-test)

\begin{tabular}{|c|c|c|c|c|c|c|}
\hline & & \multicolumn{2}{|c|}{ Paired Differences } & \multirow{2}{*}{$\mathrm{t}$} & \multirow{2}{*}{ Df } & \multirow{2}{*}{ Sig. (2-tailed) } \\
\hline & & Mean & Std. Deviation & & & \\
\hline Pair 1 & Postes - pretes & 31.167 & 6.254 & 27.297 & 29 & 0.000 \\
\hline
\end{tabular}

The results of the t-test with the paired sample t-test approach obtained a t-count value of 18.387 with a probability of $0.000<0.05$ so it was concluded that the implementation of the e-module developed on Biochemistry material was effective in increasing student HOTS with an average difference of 31.167 (Table 3).

The product developed is in the form of an e-module in the General Chemistry course for Biochemistry. Emodules are compiled and developed by taking into account the material and media aspects by using the Kvisof Flipbook Maker software or application so that students can read by feeling like reading a book physically because there is an animation effect where when switching pages it will look like physically opening a book. The e-module is designed based on HOTS and not only in the form of text, but also by inserting images, sounds, links and videos on the worksheet. The results of the expert validator's assessment of the developed emodule have been declared valid. The validity of the emodule is met qualitatively based on the assessment of the material expert validators and media expert validators which are overall stated in the valid category. through the CBT application with the results of the t-test analysis of 27.297 and $p=0.000$. Student responses to the resulting e-modules are also very positive, where students find it easier to understand and master the existing material or information, can help students learn independently by repeating the material anytime and anywhere because e-modules can be opened. on android devices, attracting students' interest and motivation in learning because the e-module is designed and equipped with interesting animations, and can improve students' HOTS abilities because the material and practice questions contained in the e-module are designed based on HOTS that train their skills critical thinking, creative, analytical ability to information and data and students' ability to solve problems.

\section{CONCLUSION}

This research and development resulted in HOTSbased e-modules on Biochemical materials. The product is developed through the ADDIE development model. The developed e-module has been declared valid and proven effective to improve students' HOTS abilities. Student responses to the resulting e-modules are also very positive because the e-modules are designed using 
the Kvisof Flipbook Maker application which can be opened on laptops, computers or Android devices so that material can be repeated anytime and anywhere and materials and questions are compiled. HOTS-based to train and improve students' HOTS skills.

\section{REFERENCES}

[1] Fanani M. Z 2018 Strategi Pengembangan Soal Higher Order Thinking Skills (HOTS) dalam Kurikulum 2013. Edudeena. 2(1) p 57-76.

[2] Barrat C 2014 Higher Order Thinking And Assessment International Seminar on current issues in Primary Education: Prodi PGSD Universitas Muhammadiyah Makasar

[3] Haig Y 2014 Higher Order Thinking And Assessment. International Seminar on current issues in Primary Education: Prodi PGSD Universitas Muhammadiyah Makasar

[4] Mislikhah S 2020 Implementasi Higher Order Thinking Skills dalam Pembelajaran Bahasa Indonesia di Madrasah Ibtidaiyah Humaniora dan Era Disrupsi, E-Prosiding Seminar Nasional Pekan Chairil Anwar. 1(1) p 582-593.

[5] Mulyaningsing I and Itaristanti 2018 Pembelajaran Bermuatan HOTS (Higher Order Thinking Skill) di Jurusan Tadris Bahasa Indonesia Indonesia Language Education and Literature. 4(1) p 114-128.

[6] Kristiyono A 2018 Urgensi dan Penerapan Higher Order Thinking Skill di Sekolah Jurnal Pendidikan Penabur. 31(17) p 36-46

[7] Suwasono 2013 Pengembangan E-Modul Online Elektronika Analog Pada Pendidikan Jarak Jauh. Teknologi dan Kejuruan. 36(1) p 51-62

[8] Priyanthi K A, Agustini K and Santyadiputra G S 2017 Pengembangan E-Modul Berbantuan Simulasi Berorientasi Pemecahan Masalah Pada Mata Pelajaran Komunikasi Data (Studi Kasus: Siswa Kelas XI TKJ SMK Negeri 3 Singaraja) Kumpulan Artikel Mahasiswa Pendidikan Teknik Informatika (KARMAPATI). 6(1) p 40-49

[9] Hidayatullah M S and Rakhmawati L 2016 Pengembangan Media Pembelajaran Berbasis Flipbook Maker Pada Mata Pelajaran Elektronika Dasar di SMK N 1 Sampang Jurnal Pendidikan Teknik Elektro. 5(1) p 83-88.

[10] Setyosari P 2013 Metode Penelitian Pendidikan dan Pengembangan (Jakarta: Kencana Prenada Media Group)
[11] Sugiyono 2013 Metode Penelitian Pendidikan Pendekatan Kuantitatif, Kualitatif, dan R\&D (Bandung: Alfabeta)

[12] Saodih N 2010 Metode Penelitian Pendidikan (Bandung: Remaja Rosdakarya) 